\title{
Egg Quality from Avian Species: Electrophoretic Characterization of Egg White Proteins
}

\author{
Meziani Samira*1, Drici Amine El-Mokhtar ${ }^{1}$, Menadi Noureddine ${ }^{1}$, Diaf Mustapha ${ }^{2}$, Zairi Mohammed ${ }^{1}$, \\ Bouterfes Mohammed and Benali Mohammed ${ }^{1}$ \\ ${ }^{1}$ Laboratory of Biotoxicology. Department of Biology-Faculty of Life Science and Nature. Djillali Liabes University. Sidi Bel \\ Abbes. Algeria. \\ 2 Health \& Environment Research Laboratory (HERL). Department of Biology-Faculty of Life Science and Nature. Djillali \\ Liabes University. Sidi Bel Abbes. Algeria. \\ *Corresponding author email: meziani_samira@yahoo.fr
}

\begin{abstract}
The aim of the present study was to evaluate and to compare the physicochemical composition of egg white, and to characterize and estimate the quantitative variations of egg white proteins of different birds' species (duck, quail, Chicken, partridge and goose). For each bird species, the whole egg temperature, weight, height, density and shape index were evaluated. After breaking the eggs, a visual examination was performed then vitelline ( $\mathrm{VI})$ and albumen (AI) indexes and the haugh unit (HU) were measured. The study of the quality and the characterization of egg white proteins were performed by Agarose Gel Electrophoresis. The total egg weight varied within a range of $(8.98 \pm 0.82 \mathrm{~g}$ to $142.91 \pm 10.34 \mathrm{~g})$ for quail and goose, respectively. The thickness of the egg yolk was almost three times higher than that of the egg white in all breeds. The egg freshness, measured by $\mathrm{HU}$, was higher in partridge, followed by quail and chicken breeds with values of $88.81 \pm 0.09$, $87.45 \pm 3.33,81.53 \pm 2.16$, respectively. The $\mathrm{VI}$ shows values of about 0.40 . The egg yolk/ white ratio ranged from 47 and the $\mathrm{pH}$ varied from 8.37 to 8.95 for all local species studied. The egg white protein content was higher for all species (up to $14.45 \mathrm{~g} / 100 \mathrm{~g}$ ). Three types of proteins are identified by agarose gel electrophoresis (ovalhibitor, ovotransferrin and ovalbumin) with a quantitative difference between bird species. Densitometric analysis shows a qualitative difference due to the presence of type C lysozyme in chicken egg white.
\end{abstract}

Key Words: Egg white, Species, Quality, Protein, Electrophoresis

\section{Introduction}

The egg is an agricultural product used as a simple human food or an ingredient in many dishes in most cultures of the world. In Algeria, domestic production of eggs for consumption reached 4.82 billion units in 2010 (Alloui and Bennoune, 2013). However, a significant part of our population prefers eggs from laying hens in farm houses, where the hens circulate freely, and this despite the exorbitant price. The egg is a perfect natural food, belonging to the rare category of complete protein foods. It contains the nine essential amino acids that our body cannot synthesize (Stadelman and Pratt., 1989). It is a good and easily renewable resource of protein, lipid, mineral and vitamin. Proteins are essential for the formation and maintenance of the tissues for the proper growth and development of the human body. In addition, they are responsible for the formation of muscles, organs, skin, hair, as well as antibodies, enzymes and hormones: all are made of proteins. Egg white is rich in high biological value protein; it is also an essential source of minerals, vitamins and easily digestible fats. Lederer (1978) estimates that egg consumption has a high nutritional value ( 2 and a half eggs equals $100 \mathrm{~g}$ of meat or fish). The egg quality includes the external characteristics, the shell egg quality and the internal properties.

The egg white is composed almost entirely of water and proteins (Ovalbumin, Globulins, Lysozyme, Ovomucine, Conalbumin, Ovomucoids and Avidin) with some minerals, which represents great originality for an edible product of animal origin $190 \%$ of the dry matter). It also contains free glucose (the primary energy source for chicken embryo). The objective of the present study is to highlight the morphological and physical characteristics (external and internal qualities) of eggs in five avian species and to evaluate quantitative and 
qualitative variations of egg white proteins and their intra specific differences on agarose gel electrophoresis.

\section{Materials and Methods}

\section{Biological material}

The study used five species (goose, duck, chicken, partridge, and quail) of local breed including twenty eggs for each species. These eggs were collected within 72 hours of being laid. The eggs came from the same poultry farm managed by a professional and were then kept under the same experimental conditions in the refrigerator of the Biochemistry laboratory. Each egg was subjected to a visual examination before and after breakage to compare the variations by the agarose gel electrophoresis technique.

External measurements on different bird species eggs

Temperature, hygrometry, weight and densitometry measurements

Temperature and hygrometer of both room and refrigerator were raised every day and results were read on an electronic thermometer screen. Each bird eggs were weighed individually using an electronic scale with an accuracy of $\pm 0.1 \mathrm{~g}$. Before breaking eggs, the egg density was evaluated in both normal and $12 \%$ salt water. The freshly laid egg density is slightly higher than 1 and does not float in normal water as in salt water.

\section{Shape index (SI)}

The shape index is a physical feature that characterizes the egg geometry (Nys, 2010). The egg length and width were measured according and described below (Egahi et al., 2013; Xiao et al., 2014; Hanusová et al., 2015):

$S I=W / L$.

SI (shape index) $=W$ (egg width $(\mathrm{mm}) / \mathrm{L}$ (length of egg $\mathrm{mm}$ )

\section{Examination of eggs after breakage Visual examination of the internal egg environment}

We broke the eggs by making a hole throughout the small end using a serrated knife. The contents of the egg were then poured onto a glass plate and were examined. The visual inspection consisted of observing color, shape, as well as the presence or absence of possible foreign bodies for each internal medium of the egg.

\section{Yolk and Albumen weight}

The yolk was carefully separated from the albumen and weighed using an electronic scale. Measurements were performed according to the following formulas (Silversides and Scott, 2001; Çağlayan et al., 2009):

Percentage of the shell $(\%)=$

Shell weight / egg weight $\times 100$

Percentage of albumen (\%) =

Weight of albumen / weight of egg $\times 100$

Percentage of yolk (\%) =

Weight of yolk / weight of egg $\times 100$

The yolk/white egg ratio was calculated to evaluate the eggs composition variations (Sauveur, 1988; Nys, 2010). It was calculated according to the following formula (Çağlayan et al., 2009): Rep Yellow / White $=$ [weight of yellow / weight of White] $\times 100$

\section{Measurement of the vitelline index and Albumen index}

The vitelline index is the ratio between the height and egg yolk diameter. It was calculated according to the following formula:

Vitelline Index (VI): Height yolk / Diameter yolk

The albumen index measure is based on three criteria: the albumen height, the albumen length, and the albumen width. It was calculated according to the formula described by several authors (Çağlayan et al., 2009; Hanusová et al., 2015): 
Albumen index $(\%)=$

[albumen height $(\mathrm{mm})] /$ [(albumen length $(\mathrm{mm})+$ albumen width $(\mathrm{mm})) / 2] \times 100$

\section{Measurement of HAUGH units}

The HAUGH Units is a criterion that allows appreciating the egg freshness (Buffet, 2010) and according to Mertens et al. (2010) Method. Haugh units was calculated using the formula given below (Silversides, 1994):

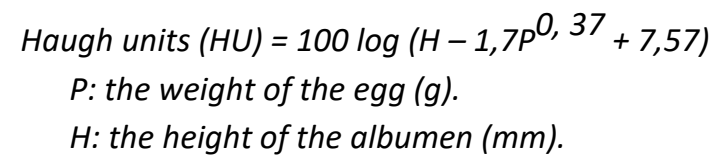

\section{Protein determination and characterization by agarose gel electrophoresis}

Determination of total egg-white protein by the method of Braford (1976), (Coomassie blue method).

\section{Preparation of the assayed samples}

After breaking of the eggs, the first step was to retrieve the egg white, once homogenize. A dilution solution in $\mathrm{pH} 10$ buffer (glycine buffer $0.1 \mathrm{M} \mathrm{NaOH}$ ) to a final volume of $200 \mathrm{ml}$, then put a quantity of $50 \mu \mathrm{l}$ taken from the previously prepared protein solution in tubes. An amount of $2 \mathrm{ml}$ of Bradford reagent was added to the three sets of tubes and mixed well and rest for 5 to 15 minutes in the dark (A count of 10 eggs was taken per population of goose, duck, chicken, partridge, and quail).

For electrophoretic characterization, $1 / 4$ dilution of the previous solutions in the buffer $\mathrm{pH} 10.100 \mu \mathrm{l}$ is mixed with identical volume of sample buffer and then boiled for $3 \mathrm{~min}$ to promote proteins denaturation. An amount of $10 \mu \mathrm{l}$ of denatured protein sample is put in each well. The agarose gel is prepared at $1 \%$ and $3 \%$ in Tris- $\mathrm{HCl}$ buffer $\mathrm{pH} 8.6 / 0.1 \mathrm{~mol} / \mathrm{l}$ under $100^{\circ}$ $C$ with stirring until the solution is perfectly homogeneous "melting gel". The size of the supports is as follows, $100 \mathrm{~mm} 51 \mathrm{~mm}$ or 0.51 $\mathrm{cm} 3$ per $\mathrm{mm}$ of gel thickness. The yellow part was separated from the white and $1 / 2$ white was diluted in Tris- $\mathrm{HCl}$ buffer $\mathrm{pH} 8.60 .1 \mathrm{~mol} / \mathrm{L}$. Bromophenol blue (BPB) was incorporated at approximately $0.5 \mathrm{mg} / \mathrm{mL}$. The deposits $(3 \mu \mathrm{L}$ ) were positioned at $1 / 3$ of the negative pole side gel. After the tank was filled with Tris- $\mathrm{HCl}$ electrophoresis buffer $\mathrm{pH} 8.60 .1 \mathrm{~mol} / \mathrm{L}$, the migration was set at about $80 \mathrm{~V} / 25 \mathrm{~min}$ using BromoPhenol Blue as a marker during migration. The gel was then fixed in methanol ( 5 $\mathrm{mn}$ ) and then stained in Coomassie blue. The drying step in the oven was done at $65{ }^{\circ} \mathrm{C}$ and then discolouration in $5 \%$ acetic acid.

\section{Data Analysis}

The data processing and analysis were carried out using three measures with the average, based on the standard deviation indicator, which describes the variability of the values of a set of data.

\section{Results and Discussion}

\section{Egg Quality}

The egg quality and stability during storage are primarily determined by their physical structure and chemical composition. The results obtained in the first experimental part are shown in Table 1.

\section{External characteristics of eggs \\ Temperature and $\mathrm{pH}$}

Temperatures were measured at the laboratory and in the refrigerator. Egg white $\mathrm{pH}$, albumen $\mathrm{pH}$ evaluated (Table 1), and the results show that the $\mathrm{pH}$ was basically stable for all breeds with an average of 8.37 to 8.95. The eggs showed temperature and $\mathrm{pH}$ variations. Measuring the $\mathrm{pH}$ of the albumen is a more accurate method in estimating the egg age. According to Sauveur (1988), after they are layed, the eggs undergo physicochemical changes, including loss of carbon dioxide and water vapour, leading to an increase in the albumen $\mathrm{pH}$ and $\mathrm{a} \mathrm{pH}$ variation, respectively (Protais et al. 1988). This $\mathrm{pH}$ increases from 7.6 to 9.3 in about two days of storage and then 
evolve slightly. After 14 to 18 days at $18^{\circ} \mathrm{C}$ and $38^{\circ} \mathrm{C}$, the average value is 9.55 and 9.6 , respectively, against 8.39 for fresh eggs according to the same author (Table 2).

\section{Weight, length and diameter}

The diameter, length and weight of the egg describe its external characteristics. The findings of the study showed egg average weight of $(8.98 \pm 0.82 \mathrm{~g}),(38.58 \pm 11.28 \mathrm{~g})(142.91 \pm 10.34$ g) for quail, partridge and goose eggs, respectively, and weight with a slight difference $(53.10 \pm 12.71 \mathrm{~g})$ and $(54.48 \pm 9.58 \mathrm{~g})$ for the eggs of the chicken and the duck, respectively.

In addition, Algeria has a Mediterranean climate in four seasons characterized by a hot climate in summer and a cold climate in winters, with a fluctuation in temperature during the year. The external and internal quality parameters are affected by environmental conditions. The environmental factors favor egg production, such as temperature, humidity, light. Several studies indicate that temperatures ranging from 4 to $31^{\circ} \mathrm{C}$ do not affect the nutrient requirements for protein, lysine or vitamin $A$, measured by growth or egg production. Egg quality is an important characteristic in poultry farming, influencing reproduction and yield (Mead and Wells, 1999; lqbal et al., 2016). Egg weight is one of the essential phenotypic parameters that affect egg quality at the yield level (Islam et al., 2001). In addition, a study by Samiullah and Chousalkar (2014) shows that age and season also influence thickness, which impacts the number of membrane fibres involved in the resistance of the shell.

A significant difference was revealed between the weight of egg whites of different breeds obtained in our tests (chicken, partridge, quail, goose and duck). The goose egg white weighted $89.318 \pm 06.46 \mathrm{~g}$, followed by duck egg white, chicken and partridge, and quail low egg white $(05.39 \pm 0.49 \mathrm{~g})$. The average weight of egg yolk for the different breeds studied is almost $50 \%$ of the egg white average weight and three times higher than the shell weight. This shell weight differs from one species to another, varying from $0.09 \mathrm{~g}$ for quail and $3.47 \mathrm{~g}$ to $10 \mathrm{~g}$ for all other species.

Table 1. The physical parameters measured from eggs of different species

\begin{tabular}{|c|c|c|c|c|c|}
\hline Species & Chicken & Patridge & Duck & Goose & Quail \\
\hline Physical characteristic & \multicolumn{5}{|c|}{ Mean \pm Standard deviation } \\
\hline WEW (gr) & $53.10 \pm 12.71$ & $38.58 \pm 11.28$ & $54.48 \pm 9.58$ & $142.91 \pm 10.34$ & $8.98 \pm 0.82$ \\
\hline $\mathrm{EL}(\mathrm{cm})$ & $4.80 \pm 0.98$ & $4.32 \pm 1.10$ & $5.78 \pm 0.75$ & $8.212 \pm 09.72$ & $3.5 \pm 04.24$ \\
\hline $\mathrm{EW}(\mathrm{cm})$ & $3.75 \pm 0.78$ & $3.21 \pm 0.86$ & $4.03 \pm 0.61$ & $5.062 \pm 07.60$ & $2.55 \pm 03.54$ \\
\hline $\mathrm{SI}(\%)$ & $78.06 \pm 0.37$ & $74.18 \pm 1.03$ & $69.63 \pm 1.49$ & $61.52 \pm 01.97$ & $72.78 \pm 01.27$ \\
\hline WW (gr) & $31.86 \pm 7.62$ & $23.72 \pm 6.94$ & $32.14 \pm 5.65$ & $89.318 \pm 06.46$ & $05.39 \pm 0.49$ \\
\hline WY (gr) & $15.93 \pm 3.81$ & $11.19 \pm 3.27$ & $16.61 \pm 2.92$ & $42.87 \pm 03.10$ & $2.69 \pm 0.25$ \\
\hline WS (gr) & $5.04 \pm 1.21$ & $3.47 \pm 1.02$ & $5.95 \pm 1.67$ & $10.00 \pm 00.72$ & $0.90 \pm 0.08$ \\
\hline $\mathrm{HW}(\mathrm{mm})$ & $3.30 \pm 0.71$ & $4.98 \pm 1.89$ & $5.26 \pm 1.07$ & $07.40 \pm 00.78$ & $03.75 \pm 0.71$ \\
\hline $\mathrm{HY}(\mathrm{mm})$ & $14.69 \pm 4.29$ & $14.19 \pm 2.55$ & $15.91 \pm 3.32$ & $19.88 \pm 05.14$ & $08.05 \pm 02.13$ \\
\hline $\mathrm{DY}(\mathrm{mm})$ & $35.05 \pm 7.74$ & $34.74 \pm 5.48$ & $37.00 \pm 7.07$ & $42.50 \pm 06.36$ & $20.00 \pm 02.83$ \\
\hline $\mathrm{TS}(\mathrm{mm})$ & $0.38 \pm 0.16$ & $0.53 \pm 0.17$ & $0.45 \pm 0.16$ & $00.50 \pm 00.11$ & $0.31 \pm 0.09$ \\
\hline $\mathrm{HU}$ & $81.53 \pm 2.16$ & $88.81 \pm 0.09$ & $73.05 \pm 4.70$ & $63.41 \pm 05.01$ & $87.45 \pm 03.33$ \\
\hline $\mathrm{Al}$ & $06.60 \pm 0.11$ & $07.21 \pm 0.22$ & $05.66 \pm 0.67$ & $04.56 \pm 0.30$ & $07.02 \pm 0.17$ \\
\hline VI & $0.42 \pm 0.03$ & $0.41 \pm 0.01$ & $0.43 \pm 0.01$ & $0.46 \pm 0.05$ & $0.40 \pm 0.05$ \\
\hline Y/W (\%) & $49 \pm 0.13$ & $47.15 \pm 0.21$ & $51 \pm 0.21$ & $48 \pm 0.25$ & $50 \pm 0.25$ \\
\hline $\mathrm{pH}^{*}$ & 8.45 & 8.40 & 8.37 & 8.95 & 8.43 \\
\hline
\end{tabular}

$\mathrm{WEW}=$ whole egg weight; $\mathrm{EL}$ = egg length; $\mathrm{EW}=$ egg width; $\mathrm{SI}=$ shape index; $\mathrm{WW}=$ weight of whites; WY = weight of the yolk; WS = weight of the shell; $\mathrm{HW}=$ height of the whites; $\mathrm{HY}=$ height of the yolk; $\mathrm{DY}=$ diameter of the yolk; TS = thickness of the shell; $\mathrm{HU}=$ Haugh Units; $\mathrm{Al}=$ Albumen index; $\mathrm{VI}=$ Vitellinic index; $\mathrm{Y} / \mathrm{W}=$ Yellow/white ration. ${ }^{*} \mathrm{pH}$ of egg white. 
Table 2. Temperature measurements in ${ }^{\circ} \mathrm{C}$ revealed at laboratory and refrigerator level

\begin{tabular}{lccccccc}
\hline Days & 01 & 02 & 03 & 04 & 05 & 06 & Average \\
\hline Laboratory & 27 & 25 & 23 & 28 & 30 & 28 & $26.8 \pm 2.5$ \\
Fridge & 03.5 & 04 & 03.5 & 04 & 05.5 & 04.5 & $4.1 \pm 0.2$ \\
\hline
\end{tabular}

A higher proportion of yolk can be considered favorable in terms of the egg nutritional value and this was true for the goose egg yolk, with registered value at $(42.87 \pm 03.10)$. These weights, however, are lower than those obtained by Sauveur (1988) in the distribution of different parts of the egg in several species of domestic birds. Previous findings showed a variation of egg and its weight at a range of $9 \mathrm{~g}$ for the quail to $200 \mathrm{~g}$ for the goose according to (Lafon and Lafon, 2009; Nau et al., 2010). The difference in the results on the weight of the eggs of the different breeds would probably be due to the evaporation of eggs contents during experimental storage and at age. Older chickens lay big eggs. Conservation is the best way to ensure good internal morphology from certain external parameters. According to a study conducted by Roriz et al. (2016), it indicated that a shelf life of up to 5 days is strongly recommended to maintain a good quality of egg. On the other hand, the egg weight depends mainly on breed (genetic origin and especially age) and diet composition during the laying period.

Diet contributes indirectly by influencing sexual maturity, body weight and body composition at the production period (Bouvarel et al., 2010). In addition, according to the weight criterion of our eggs, our study classifies eggs by weight (Figure 1). According to Mein et al. (2015), it was indicated that when weight is larger than $73 \mathrm{~g}$, the egg is of category $\mathrm{XL}$ (very large egg and extra fresh), $63 \mathrm{~g}$ and $73 \mathrm{~g}$ is of category L (big egg, $53 \mathrm{~g}$ and $63 \mathrm{~g}$, is of category $M$ (medium egg) and less than $53 \mathrm{~g}$ is of category S (egg small). Regarding the length, the mean values are $(8.21 \mathrm{~cm} \pm 09.72)$ for goose eggs with a width $(5.06 \mathrm{~cm} \pm 07.60)$. Lower values were found for eggs of three species (chicken, partridge and duck) ranging from $(3.75 \mathrm{~g} \pm 0.78)$ to $(4.03 \mathrm{~g} \pm 0.61)$. According to Alkan et al. (2008), the width of the egg is the most accurate criterion for predicting yolk height. The results obtained for the height are shown in Table1. The height of egg yolk is almost three times higher than the height of egg white for all breeds. The highest average height recorded for the goose breed is almost $20 \mathrm{~mm}$ and the recorded gap is 05.14 (maximum value) and $2.13 \mathrm{~mm}$ (minimum value).

\section{Internal characteristics of eggs}

Eggs are genetically dependent on three major components: shell, yolk and albumen. The internal egg quality is influenced by factors such as storage, bird strain and age, nutrition, presence of contaminants, the medications, feed ingredients, or chemicals used in agriculture.

\section{Vitelline index measurements}

The vitellinic index is a very sensitive parameter to egg age determination. This index can range from 0.10 to 0.54 as indicated by Bijve (2006), from 0.2 to 0.62 by Athias (2003), from 0.21 to 0.67 according to N'Diaye (2002). Our study allowed us to record stable yolk values with an average grade of 0.40 . Regarding the Yellow/White ratio report, a slight difference was observed for all local breeds studied, i.e. $47 \%: 51 \%$. The high percentage of white can explain these results compared to yellow in local breeds. The results can also be linked to genes responsible for these disproportions between the different components of the egg. The yellow index depends on the vitelline membrane quality and, therefore, the egg freshness. A fresh egg of good quality has a yellow index of 0.45 
(Mertens et al., 2009), and the findings of the current study showed slightly higher yellow index. Another study conducted in the NorthWest of Algeria by Halbouche et al. (2009), that the $\mathrm{Y} / \mathrm{W}$ ratio of eggs collected from farmers was (44.95), which is lower than the index obtained in this study. The difference can be explained by the weight loss of the white in favor of the yellow's weight under the laboratory's storage conditions.

\section{Haugh units (HU)}

The Haugh unit determines the egg freshness, the values show higher freshness in partridge eggs followed by quail and chicken eggs with values of $(88.81 \pm 0.09,87.45 \pm 03.33$, $81.53 \pm 2.16)$, respectively. An average value was found in goose eggs $(63.41 \pm 05.01)$ which were less fresh. The Haugh Unit is a measure of the quality of egg protein according to the egg white height. Raymond Haugh introduced the test in 1937, which is an important measure of egg quality and other measures such as shell thickness (Haugh, 1937; USDA, 2000). According to a study conducted by Akouango (2014), eggs with Haugh Unit more than 70 are considered excellent eggs, between 60 and 70 are acceptable, while those that show a Haugh Unit less than 60 are poor quality (Figure 1). In this study, four species whose UH have eggs greater than 70 and are considered excellent quality, while the goose eggs whose $\mathrm{UH}$ is acceptable. The units of Haugh vary from one breed to another (Moula, 2018), which would explain the differences recorded in this study.

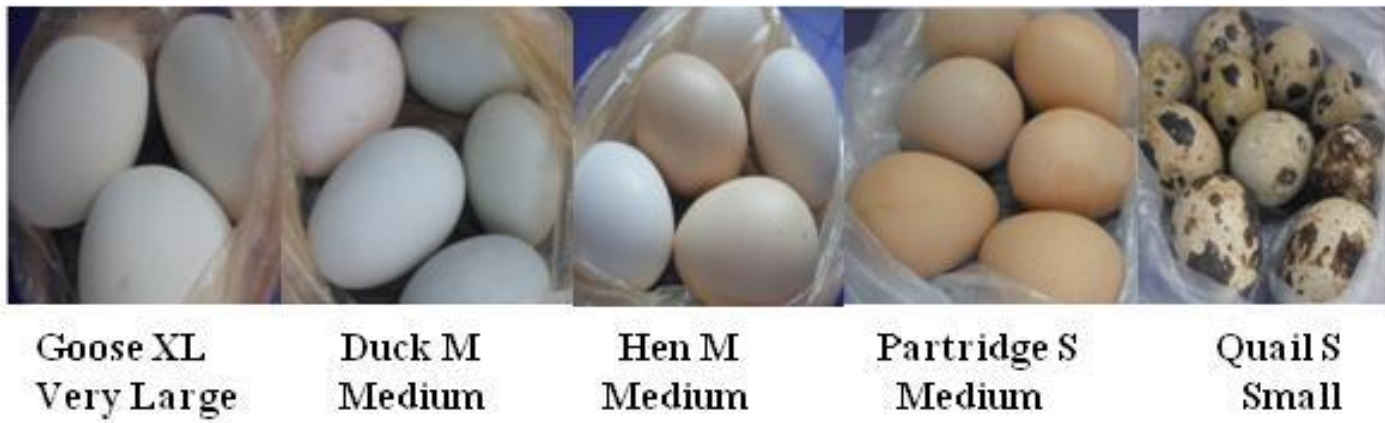

WEIGHT

$$
142 \geq \mathrm{g} 73 \mathrm{~g} \quad 53 \mathrm{~g} \leq 54.5 \mathrm{~g} \leq 63 \mathrm{~g} \quad 53 \mathrm{~g} \leq 53 \mathrm{~g} \leq 63 \mathrm{~g}
$$

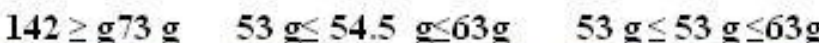

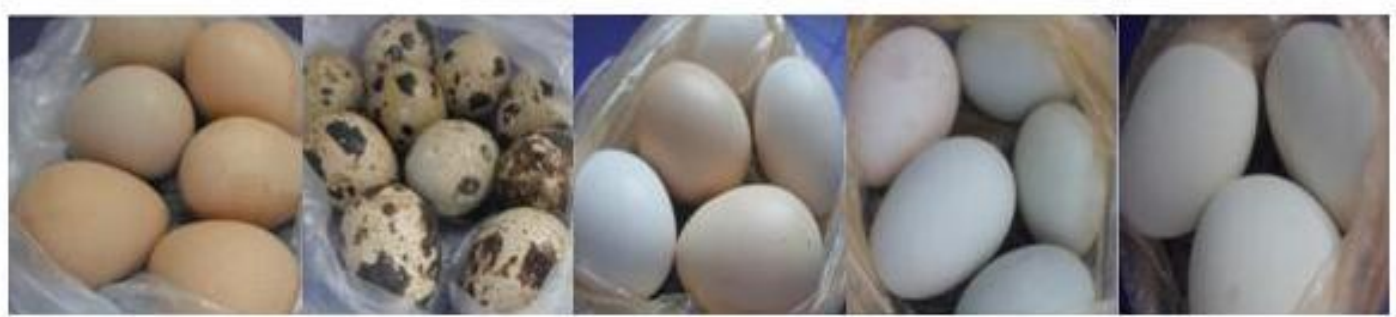

$\begin{array}{lcccc}\begin{array}{l}\text { Partridge } \\ \text { Excellent }\end{array} & \begin{array}{c}\text { Quail } \\ \text { Excellent }\end{array} & \begin{array}{c}\text { Hen } \\ \text { Excellent }\end{array} & \begin{array}{c}\text { Cane } \\ \text { Excellent }\end{array} & \begin{array}{c}\text { Goose } \\ \text { Acceptable }\end{array} \\ & & \text { HAUGH UNTT } & \\ 88.81>70 & 87.4>70 & 81.53>70 & 73.05>70 & 60<61.43>70\end{array}$

Figure 1. Classification of eggs by weight category and quality per Haugh Unit Eggs of different breeds (Goose, Chicken, Cane, Partridge, Quail). 


\section{Total protein yield of egg white}

\section{Protein assay results}

This method makes assay proteins of between 0.1 and $1 \mathrm{mg} / \mathrm{ml}$ (Bradford, 1976). Initially, the assay consists of adding $100 \mu$ l of appropriately diluted sample to $5 \mathrm{ml}$ of Bradford reagent. The mixture, after homogenization is then placed in the dark for $5 \mathrm{~min}$, and the absorbance is measured at $595 \mathrm{~nm}$. Protein concentrations were calculated by linear interpolation from a standard range containing bovine serum albumin (The BSA standard range at $1 \mathrm{mg} / \mathrm{ml}$ ).

\section{The protein content in $\mathrm{g} / 100 \mathrm{~g}$ of the egg white}

In general, egg white consists of $10.6 \%$ of globular proteins, the main-one being called ovalbumin (more than $50 \%$ of all proteins). The other main white proteins are lysozyme and ovotransferrin ( $\mathrm{Nau}$ et al., 2010). The protein concentration of the samples studied is determined either graphically by the use of the standard curve, or by applying the following equation to calculate the concentrations from the recorded optical density values: $y=0.010 x$ $+0.026$

The amount of protein contained in 100g of the edible parts from the weight and volume values of each of the previously measured eggs was calculated. The results obtained are shown in table 3 below. Based on the results, total protein levels are high, except for the duck egg where the recorded rate was $11.65 \mathrm{~g} / 100 \mathrm{~g}$, which shows a very high homogeneity between the different species. Egg white consists of $10.6 \%$ globular proteins ( $\mathrm{Nau}$ et al., 2010). According to a recent study conducted by Abeyrathne et al. (2013), egg white contains many functionally essential proteins. Ovalbumin (54\%), ovotransferrin (12\%), ovomucoid (11\%), ovomucin (3.5\%) and lysozyme (3.5\%) are among the main proteins with high potential for industrial applications if they are separated. In addition, the overall composition of egg white in $\%$ of the main bird species cited by (Romanoff and Romanoff, 1949), $10.6 \%$ for the chicken, $11.5-11.60 \%$ for cane and goose. The findings of this study are higher than those cited in these previous studies. The variations of major elements in egg content are attributed to the white and yellow proportions that vary significantly depending on: (01) the egg weight, and (02) the egg age. The chicken and the dry matter contents of the two compartments are very different (Sauveur, 1988).

\section{Agarose gel electrophoresis separation results from bird egg white proteins}

The birds egg white has different proteins in common to highlight their phylogenetic relationship. The comparison of these proteins in different species can be used to evaluate the quality and the qualitative variations (Absence/Presence) of these proteins of different avian species by agarose gel. Similar results can be obtained with a $1 \%$ and $3 \%$ cast agarose gel under the same conditions with a slight difference in protein resolution.

However, it should be noted that the resolution of the egg white proteins is better with an agarose gel. In the current study, several preliminary tests were conducted in order to obtain a gel with a good resolution in which protein fractions are well separated. In the example below, two gels were prepared, and seven tracks of an agarose gel were loaded with 5 and $7 \mu \mathrm{L}$ of diluted egg white and lysozyme extracted from egg white from five birds. The electrophoresis was conducted at 100 $\mathrm{V}$ for 30 and $\mathbf{4 0}$ minutes. A protein will migrate on its support the more quickly that its global charge is high and that its size is reduced: one will be able to locate the different types of proteins contained in the initial mixture (they will form successive bands after treatment and coloration in blue of Coomassie. The comparison of the various protein extracts of the egg white can be conducted by a simple visual examination of the electrophoresis tracks, but the comparison of the densitometric-profile 
brings with more precision. There is a greater diversity of albumen proteins that show several bands of neighboring or identical mobility suggesting.

Three bands are distinguished, two major at the top and bottom of the gel. Towards the positive pole, three bands should be, according to the standards used (Bovine Serum Albumin), ovotransferrin at the top $(77,7 \mathrm{KDa})$, ovalbumin at the bottom ( $45 \mathrm{KDa}$ ) because it is the more abundant egg white protein (54\%), and probably the ovoinhibitor just above the latter giving a thinner band, the weaker band that is immediately at the top of the latter is the ovoinhibiteur (49 KDa) (Desert et al., 2001; Lechevalier, 2005). A study by Desert et al. (2001) showed that some bands do not migrate. These should be proteins that are unable to penetrate the gel. This could be due to their high molecular weight, so it would be either ovomucin, ovostatin or protein aggregates.

The negative pole, should contain lysozyme, but this protein is too small (14 KDa) (Lysozyme used as standart) (Nau et al., 2010). Regarding pl values, several known egg white proteins, only avidin and lysozyme with pls of 10 and 10.7, respectively, are positively charged, so they should not migrate to the anode and remain in the same direction. This study showed absence of the band of lysozyme on the gel of the figure 2 for all the species except for the chicken, or a faint band was noticed using the $1 \%$ agarose gel, and clearer in 3\% agarose gel. Larger differences have been observed for lysozyme, so much so that two types are distinguished in birds; of which type C lysozyme, such as that found in chicken eggs (Nau et al., 2010).

Table 3. Quantity of protein and lysozyme in $\mathrm{g} / 100 \mathrm{~g}$ of egg white and lysozyme

\begin{tabular}{cccccc}
\hline Species & Partrdge & Duck & Chicken & Goose & Quail \\
\hline Proteins (g/100g) & 14.45 & 11.65 & 14.25 & 14.02 & 14.21 \\
Lysozyme in 20\% & 2.15 & 3.55 & 2.4 & 2.5 & 0.9 \\
Lysozyme in 40\% & 0.7 & 2.8 & 0.55 & 1.5 & 0.45 \\
\hline
\end{tabular}

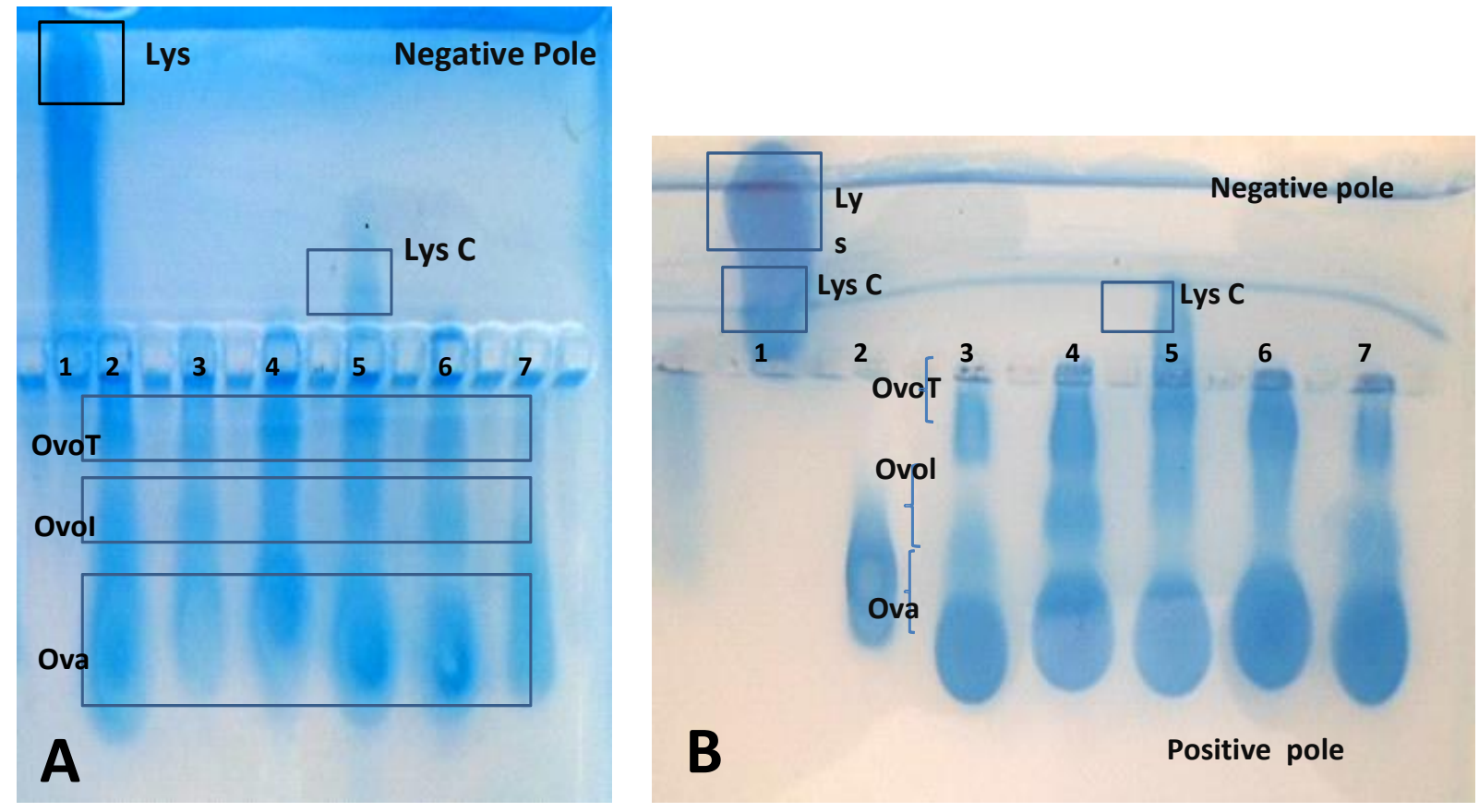

Figure 2. Results of an egg white protein in electrophoresis gel on $1 \%(\mathrm{~A})$ and on $3 \%(\mathrm{~B})$ agarose gel. 1. Lysozyme Marker, 2.BSA Marker, 3.Duck, 4.Quail, 5.Chicken, 6.Partridge, 7.Goose. Ova: Ovalbumine (45 KDa), Ovol: Ovoinhibitor (49 KDa), OvoT: Ovotransferrine (77,7 KDa) 


\section{Conclusions}

This study provides information on eggs' physical, external and internal characteristics in five species of local breed poultry (quail, duck, Chicken, goose, partridge). Our results allow us to conclude a remarkable difference in terms of whole weight, conformation and internal composition between eggs. The quality of the eggs was not uniform, which could be attributed to several factors such as age and breed, storage conditions, feeding, etc.

\section{References}

Abeyrathne, ED , H Lee, and D Ahn. 2013. Egg white proteins and their potential use in food processing or as nutraceuticals and pharmaceuticals a review.Poult Sci . 92 : 3292 à 3299.

Akouango, P. 2014. Qualitative and quantitative evolution of the components of the egg during the three laying phases in the hen. Journal of Applied Biosciences. 74:6080-6085.

Alkan, CT, SK Karabag, A Galic, and M S Balcioglu. 2008. Effects of genotype and egg weight on hatchability traits and hatching weight in Japanese quail. S. Afr. J. Anim. Sci. 38 (3):231237.

Alloui, N, and O Bennoune. 2013. Poultry production in Algeria: Current situation and future prospects. World's Poultry Science Journal, 69, pp.613-619.

Athias, A. 2003. Contribution to the comparative study of the commercial quality of eggs from the market and eggs from supermarkets: the case of the urban area of the city of Abidjan.Th.Méd. Ve.

Bijve, Y. 2006. Etude l'évolution des œufs de consommation dans les conditions de stockage naturellesTh. :Méd.Vét: Dakar.

Bouvarel, I, Y Nys, M Panheleux, and P Lescoat. 2010. How does chicken feeding influence the quality of eggs ?. Inra Productions Animales. 23(2), pp.167182.

Bradford, MM. 1976. A rapid and sensitive method for the quantification of microgram quantities of protein utilizing the principle of protein-dye biding. Analytical Biochemistry, 72 : 248-254.

Buffet, E. 2010. Packaging and packaging of eggs for consumption. In: F. Nau, C. Guérin-Dubiard, F. Baron, J L. Thapon, eds. 2010. Egg science and technology. Paris: Tec and Doc Lavoisier. 251263.

Desert, C, CGF Nau, G Jan, F Val, and J Mallard. 2001. Comparison of different electrophoretic separations of hen egg white proteins. J. Agric. Food Chem. 49:4553-4561

Egahi, JO, NI Dim, and OM Momoh. 2013. The effect of plumage modifier genes on quality indices of the nigerian local chicken. Journal of Agriculture and Veterinary Science, 2(2), pp.04-06.

Halbouche, M, L Dahoum, A Mouatz, M Didi, S Ghali, W Boudjenah, and A Fellahi. 2009. Phenotypic inventory of local poultry populations in the Algerian North-West, morphological characterization of animals and eggs. Proceedings of the First Study Days: local poultry genetic resources. Mostaganem, Algeria, June 23-24.

Hanusová, E, C Hrnčár, A Hanus, and M Oravcová. 2015. Effect of breed on some parameters of egg quality in laying hens. Acta Fytotechnica et Zootechnica, 18(1), pp.20-24

Haugh, RR. 1937. The Haugh unit for measuring egg quality. U.S. Egg Poultry Magazine, No. 43, pages 552-555 and 572-573.

Iqbal, J, SH Khan, N Mukhtar, T Ahmed, and RA Pasha. 2016. Effects of Egg size (Weight) and Age on Hatching Performance and Chick Quality of Broiler Breeder. Journal of Applied Animal Research, 44, 54-64. https://doi.org/10.1080/09712119.2014.987294.

Islam, M, S Bulbul, G Seeland, and ABM Islam. 2001. Qualité des œufs de différents génotypes de poulet en été et en hiver. Pakistan Journal of Biological Sciences, 4, 1411-1414. https://doi.org/10.3923/pjbs.2001.1411.141

Lafon, PH and F Lafon. 2009. L'œuf et les ovoproduits. Technique de l'ingénieur. F7010.121. Journal of the Science of Food and Agriculture, 89(3), pp.379-383

Lechevalier, V. 2005. Shearing, creation of interfaces and heat treatment. Doctoral thesis in physicochemistry and quality of bioproducts. Life- AgroHealth doctoral school.

Lederer, J. 1978. Encyclopédie moderne de I'hygiène alimentaire. Paris : Maloine.-870 p.

Mead, GC, and RG Wells. 1999. Poultry Meat Science. $C A B$ International Publishing, Wallingford.

Mein. 2015. Technical specifications applicable to eggs and egg products. Regulatory document produced by the study group of collective catering and nutrition (GEM-RCN). Paris: Ministry of Economy, Industry and Digital (France).

Mertens, FN, C Guérin-Dubiard, F Baron, and JL Thapon. 2010. Physico-chemical quality of the consumer egg. Science and technology of the egg: Volume 2, From egg to egg products, Lavoisier, p.7

Moula. 2018. Quality of eggs for consumption of three genetic types of hens marketed in eastern 
Algeria Article in Archivos de Zootecnia - August 2018 DOI: 10.21071/az.v67i259.3791.

N'diaye, A. 2002. Contribution to the commercial quality of eggs for consumption in the Dakar Region. Thesis: Med. Vet .: Dakar; 16.

Nau, F, Y Nys, Y Yamakawa, and S Rehault-Godbert. 2010. Nutritional interest of the egg in human food. INRA Animal Production 23 (2): 225-236.

Nys, Y, J Gautron, JM Garcia-Ruiz, and MT Hincke. 2004. Avian eggshell mineralization: biochemical and functional characterization of matrix proteins. Comptes. Rendus Palevol 36), 549-562.

Protais, J, Lahellec and M Launay. 1981. Variations in the internal quality of the egg with storage temperature. Bul. inf. Station Exp. ploufragan poultry. 21, (1), 1981: 39-41

Protais, M. 2010. Genetic selection and production of layers. In: F. Nau, C. Guérin Dubiard, F. Baron, J L. Thapon, eds. 2010. Egg science and technology. Paris: Tec quality characteristics of chicken. International Journal of Poultry Science. 2(4), pp.261-263.

Romanoff, A, and AJ Romanoff. 1949. The Avian Egg. (New York, John Wiley). USA. SAS (2003): The SAS System for Windows. Release 9.1.3. SAS Institute Inc.

Roriz, BC, S Sgavioli, RG Garcia, IA Nääs, CHF Domingues, FR Caldara, L Rombola, CM Ayla, and K Bernnecke. 2016. Storage Period Affects Weight Loss of Japanese Quail Eggs. / v.18 / n.4 / 589-592. Rev. Bras. Cienc. Avic. vol.18 no.4 Campinas Oct./Dec. 2016. http://dx.doi.org/10.1590/1806-9061-2015-0178
Samiullah, RJR, and KK Chousalkar. 2014. Effet du système de production et de l'âge du troupeau sur la qualité des œufs et la charge bactérienne totale chez les poules pondeuses commerciales. Journal of Applied Poultry Research, 23, 59-70. https://doi.org/10.3382/japr.2013

Sauveur, B. 1988. Structure, composition and nutritional value of the egg. In Reproduction of poultry and egg production. Edition: INRA. ISBN: 2853409619. 347-436.

Silversides, FG, and TA Scott. 2001. Effect of storage and layer age on quality of eggs from two lines of hens. Poultry Science, 80(8), pp.1240-1245.

Silversides, FG. 1994. The Haugh unit correction for egg weight is not adequate for comparing eggs from chickens of different lines. The Journal of Applied Poultry Research, 3(2), pp.120-126

Stadelman, W, and OJ Cotterill. 2001. Egg Science and Technology. 4th ed. Avi Publ. Co., Westport.

United States Department of Agriculture, Agricultural Marketing Service. 2000. Egg-Grading Manual. Agricultural Handbook No. 75. USDA, July 2000.www.ams.usda.gov/poultry/pdfs/EggGra ding\%20manual.pdf .A description of the Haugh procedure is on folio pages 34 and 35 .

Xiao, JF, YN Zhang, SG Wu, HJ Zhang, HY Yue, and G.H. Qi. 2014. Manganese supplementation enhances the synthesis of glycosaminoglycan in eggshell membrane: A strategy to improve eggshell quality in laying hens. Poultry Science, 93 (2), pp.380-388. 